\title{
SELF-DETERMINED LEARNING AS A RESPONSE TO DISRUPTION IN POST-SECONDARY FORMAL EDUCATION
}

\author{
Steve Henry
}

\section{INTRODUCTION}

As the institutions of higher education strive to meet the challenges of a profoundly changing world (Friday \& Halloran, 2020), questions about shape and purpose gain increasing urgency. The speed at which many institutions adjusted to the coronavirus pandemic sweeping the world in early 2020 illustrates that quick change is possible (Eisenstein, 2020; Hess, 2020). We have entered a new transformative age and, much like the industrial revolution before it, we can expect fundamental shifts in how we live, work and play (Friday \& Halloran, 2020).

While many of the apparent certainties of twentieth-century life have been disrupted over the past decade or two - from banking to travel, communication to accommodation, and in many other spheres' - education and health care have been largely immune (Christensen et al., 2017; Walsh, 2020). This paper examines the prospects for a transformation in self-determined vocational post-secondary learning in Aotearoa-New Zealand. ${ }^{2}$

\section{HIGHER EDUCATION IS CHANGING}

Recent research into the drivers of change in vocational institutions and universities - from interviews of 45 chief executive officers from across Australasia by Friday and Halloran (2020) - indicates that current models are no longer fit for purpose (see Figure I).

The funnel metaphor in Figure I illustrates key factors contributing to the looming crisis. In Aotearoa-New Zealand, those same factors have precipitated a thoroughgoing structural reform of the vocational education sector (Ministry of Education, 20/9). In the consultation contributing to the reform propiosal, 74 percent of the 745 submissions agreed there needs to be change. This raises the question of the purpose of such education - expressed in the Tertiary

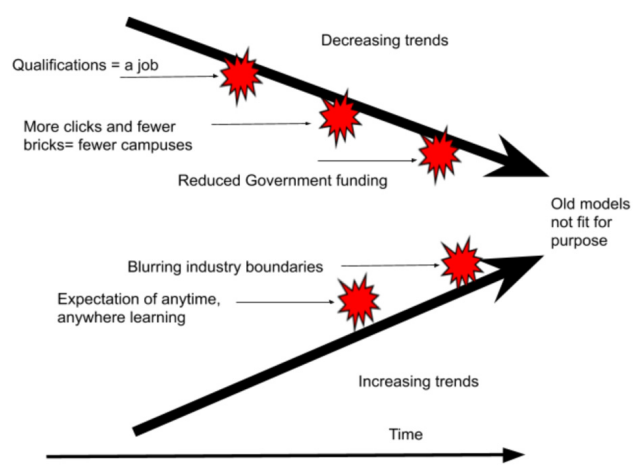

Figure I. Drivers of change in higher education. Education Commission's strategy (Tertiary Education Commission, 2019) as:

- Delivering skills for industry

- Getting at-risk young people into a career

- Boosting achievement for Pasifika 
- Boosting achievement for Māori

- Improving adult numeracy and literacy

- $\quad$ Strengthening research-based institutions

- Growing international linkages.

This strategy defines success, yet it is not clear that there is agreement on how best to achieve it (Education Central, 2019).

While the importance of workplace learning has been identified by New Zealand's Productivity Commission (20 I9), because of the need for a flexible training system that can accommodate both provider-led and workplace-led approaches, and the need to widen access to work-based education and training, a respected leader in vocational education has called the current approach "a woefully inadequate funding system that has been failing New Zealand for at least a decade" (P. Ker, quoted in Anon, 2020).

Elsewhere - in The Netherlands, South Africa and England, for example - young people have negative perceptions about the value of vocational education (Atkins \& Flint, 20I5). Yet ironically, in the US there is a lack of work-ready graduates, with universities criticised by leaders in commerce and industry (Smith, 2020). Employers such as Google, Apple, IBM and Ernst \& Young no longer require new recruits to have traditional university degrees, even for highly skilled positions (Smith, 2020).

Annual Streaming Price

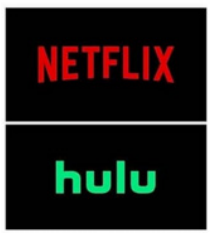

$\$ 108$

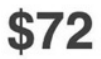

\section{You Tubered $\$ 120$}

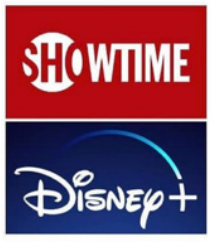

$\$ 132$

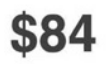

\section{圈 HARVARD $\$ \mathbf{5 0 , 4 2 0}$}

Figure 2. Annual streaming prices for selected entertainment providers compared with Harvard University's online course fee (from Tabarrok, 2020).
Smith (2020) claims that education delivery has been unchanged for so long that the model has been conflated with the mission. Universities comprise 70 of the 85 institutions in the West that have endured in recognisable form since the 1520s (Kerr, 200 I). That stability has bred overconfidence, overpricing and an overreliance on business models tailored to a physical world (Smith, 2020). Figure 2 illustrates the disparity between the costs of a selection of streamed entertainment offerings in the US and the costs Harvard University charge for online courses (Anderson, 2020). Querying the sustainability of such fees, the Wall Street Journal (2020) has asked: "Would you pay $\$ 75,000$ for front-row seats to a Beyoncé concert and be satisfied with a livestream instead?"

Transformation is inevitable if higher education institutions are to preserve their relevance, or the services they offer will be sought elsewhere. There are mature and respected online offerings already available: Coursera (at www.coursera.org) and the Khan Academy (at www.khanacademy.org), to cite just two of many. Originally dismissed as a threat to higher education (Smith, 2020), these platforms provide customisable content, something that the campus-based institutions have failed to accomplish. Olsson et al. (2004) argue that what is needed is nothing short of major transformation - not only in policies and technologies, but in modes of innovation - to enable users to navigate turbulence. According to Lyngsø (2017), the rules have already changed: whereas the old rules focussed on more - more growth, speed, profit, processes and the fear of systematic breakdowns - the new rules are about better. better value creation, people, positive impact and the need to break the rules. 


\section{THE CHANGING EDUCATION SYSTEM}

\begin{tabular}{|llll|}
\hline Meaning is... & Dictated & Socially constructed & $\begin{array}{l}\text { Socially constructed and contextually } \\
\text { reinvented }\end{array}$ \\
\hline Technology is... & $\begin{array}{l}\text { Confiscated at the } \\
\text { classroom door (digital } \\
\text { refugees) }\end{array}$ & $\begin{array}{l}\text { Cautiously adopted (digital } \\
\text { immigrants) }\end{array}$ & Everywhere (digital universe) \\
\hline $\begin{array}{l}\text { Teaching is done } \\
\text {.. }\end{array}$ & Teacher to student & $\begin{array}{l}\text { Teacher to student and } \\
\text { student to student } \\
\text { (progressivism) }\end{array}$ & $\begin{array}{l}\text { Teacher to student, student to student, } \\
\text { student to teacher, people-technology- } \\
\text { people (co-constructivism) }\end{array}$ \\
\hline $\begin{array}{l}\text { Schools are } \\
\text { located... }\end{array}$ & In a building (brick) & $\begin{array}{l}\text { In a building or online } \\
\text { (brick and click) }\end{array}$ & $\begin{array}{l}\text { Everywhere (thoroughly infused into } \\
\text { society: cafes, bowling alleys, bars, } \\
\text { workplaces, etc.) }\end{array}$ \\
\hline $\begin{array}{l}\text { Parents view } \\
\text { schools as... }\end{array}$ & Daycare & Daycare & A place for them to learn, too \\
\hline Teachers are... & Licensed professionals & Licensed professionals & Everybody, everywhere \\
\hline $\begin{array}{l}\text { Hardware and } \\
\text { software in } \\
\text { schools... }\end{array}$ & $\begin{array}{l}\text { Are purchased at great } \\
\text { cost and ignored }\end{array}$ & $\begin{array}{l}\text { Are open source and } \\
\text { available at lower cost }\end{array}$ & $\begin{array}{l}\text { Are available at low cost and are used } \\
\text { purposively }\end{array}$ \\
\hline $\begin{array}{l}\text { Industry views } \\
\text { graduates as... }\end{array}$ & Assembly line workers & $\begin{array}{l}\text { As ill-prepared assembly } \\
\text { line workers in a } \\
\text { knowledge economy }\end{array}$ & As co-workers or entrepreneurs \\
\hline
\end{tabular}

Figure 3. New paradigm model education, from 1.0 to 3.0 (after Moravec, 2008).

Horn (2014) describes a continuum from Education 1.0 to Education 3.0: moving beyond mass education to mass-customised education through blended learning, using the flexibility of technology to help students of varying backgrounds and skills. Education 1.0 is deeply embedded in the way higher education has and continues to operate. The significance of this change is summarised in Figure 3, with major shifts such as the clear role of teaching experts in Education 1.0 and 2.0 changing, and the place of a physical space being less important in Education 3.0.

Education 1.0 is the default position of traditional pedagogy, where the learner is dependent on the educatorl teacher who controls the setting, content and process of learning, usually with prescribed curricula - where knowledge transfer is the purpose of learning for defined roles in society. The motivation for such learning is usually external to the learner, with formal structures such as classes, examinations and social validation for completion.

Education I.0's pedagogy is limited by the investment in deconstructing meaning and aligning its relevance directly to the uniqueness of the learner - and is problematic when transferred from children to adult learners. The advantage of this pedagogical approach is that experienced educators can support learners to develop desired behaviours and develop skills through defined, regulated stages, as occurs with high-risk professions (BoardShare, n.d.).

In self-determined learning (heutagogy), content and process emerge through enquiry, as suggested by Wade and Kenyon (2013). The desire for relevance is essential in adult learning, when increased choice is present. Learners become self-directed in the shift to intrinsic motivation (ibid.), seeking guidance and mentorship. Other stakeholders may influence learning destinations - employers, quality-control councils and teachers, as they guide and facilitate learning - but the learner is the central character. Educators enable a range of approaches for the learner to reach their agreed destination, while earners rely on subject-area experts to deliver knowledge and scaffolding. Aspects of this approach may occur in some post-secondary formal learning where learners have choice as to the focus of investigations, yet pedagogy remains firmly behind such structures and the power lies with the educator who determines this (ibid). According to Mann et al. (2017), the desire to learn has several implications or variations: humility over wilful ignorance; curiosity over fixed cognitive maps; and challenging assumptions over accepting a status quo. 
Self-determined learning can also be a vehicle for making sense of uncertainty (Bhoryrub et al., 20l0) or, to summarise Anderson (2020, p. 40), enabling learners to surf at the edge of chaos as a response to disruption. Bhoryrub et al. (2010) describe nursing practice as themed with complexity and unpredictability, and hence uncertainty, and argue that the learner, from a heutagogical perspective, is the only relative constant within an environment of unpredictable variables, and hence is best placed to direct and embed learning as it arises. This approach is relevant to other professionals, especially in a time of disruption. Pferdt (2020) recommends three mindsets to help navigate the future in these times of crisis and change:

I. Embrace empathy

2. Ask the question, "How can we ...?"

3. Cultivate your experimental mindset.

Self-determined learners control the content and process of their learning through enquiry and, perhaps more importantly, through their mindset. Self-determined learning enables a fully inclusive education which responds to disruption, based on the potential of the human capacity to create (Robinson, 2006), and which honours each person's unique talent and potential. The questions being asked by a teacher and learner give a clear indication of how much self-education occurs, and where the power in the relationship between learner and teacher lies (Figure 4).

\section{TRANSFORMATION IN THE HIGHER EDUCATION CONTEXT}

Researching how best higher education could operate in 2030, Friday and Halloran (2020, p. 30) recommended that institutions should consider their potential to:

I. Embark on transformation to optimise and grow

2. Make the shift from being faculty-focused to learner-centric

3. Integrate with industry to collaborate

4. Re-imagine the physical campus for the digital world

5. Unbundle degree programs and the university value chain.

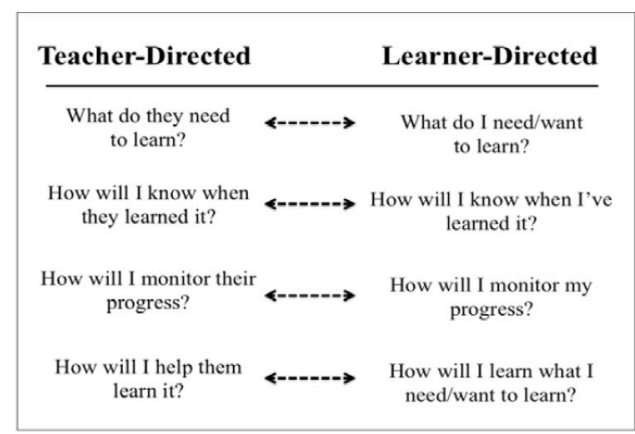

Figure 4. Teacher- vs learner-directed questions (after Bull, 20|4).

According to Mezirow (2003, pp. 58-63), a pioneer of transformation literature, perspective transformation is achieved through:

I. disorienting dilemmas,

2. critical reflection,

3. rational dialogue and

4. action. 
Transformation is an uncomfortable fit for risk-averse institutions, which have changed little over centuries, so disorientation is not welcomed. The coronavirus pandemic has shown how patterns of disruption can lead to innovation, with a rapid shift from campus-based learning to online, with learners and staff working from home. This disruption provides an opportunity to re-think how formal education is delivered and customised for the individual. The ability to offer programmes away from campuses in a work-based setting offers much resilience. Alden-Rivers et al. (20I4) call for this movement of change, social innovation and impact to be embedded within all facets of society, especially within education.

\section{EDUCATION THAT IS INCLUSIVE OF EVERY CULTURE}

The culture and place of the individual can be overlooked when educators presume that all learners identify with the same or similar culture, despite recognising the detrimental effects of this disassociation (Hook, 2007). Inherent in the Education 1.0 paradigm is the entrenchment (conscious or otherwise) of neocolonial attitudes and approaches (Smith, 2008).

Spiller et al. (201 I) describe a solution, a meeting place between cultures called a wisdom position. Taking this approach forward, Huitt (2004) suggests moving beyond Maslow's conventional hierarchy of needs (Maslow, 1943) to a perspective where community actualisation is achieved through self-actualisation or self-transcendence. This is a large step from the individual achievement focus of Education 1.0 and 2.0.

There are increasingly clear pathways to change the impacts of colonisation. Durie (2004) has suggested that Aotearoa-New Zealand has three significant advantages favouring equitable outcomes for Māori:

I. The Māori population is a large minority ( 15 percent, predicted to rise to 20 percent by 2050)

2. The Treaty of Waitangi's partnership between Māori and the Crown

3. Effective Māori leadership for more than a century.

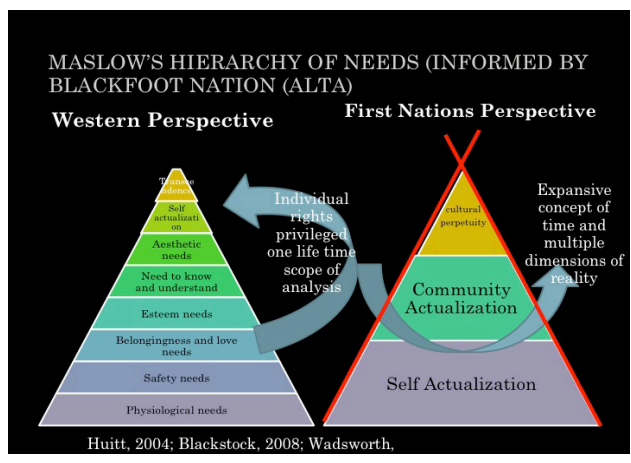

Figure 5. Maslow's hierarchy of needs informed by an indigenous (first nation) perspective (Huitt, 2004).

Increasingly, Pakāhā (for our purposes, non-Maori

New Zealanders) are becoming aware of the need to honour the partnership in the Treaty of Waitangi in education. Decolonising research methodologies are being articulated (Smith, 2008). Institutions such as Otago Polytechnic have Māori strategic plans which mandate the inclusion of a Māori world view in every learning programme (Otago Polytechnic, 2016). The New Zealand government is actively prioritising an increase in historically poor education outcomes for Māori (Tertiary Education Commission, 20 19). There is much learning to come, as Hunt (2020, p. I3) has bluntly summarised: "[W] e need to open our eyes to where we have benefited from colonisation but never truly acknowledged it, we as Pākehā must do a better job of recognising the grief and trauma that have been passed down to today's Māori."

Self-determined learning customised by the learner, such as the design of Capable NZ's independent learning pathways (ILPs; see Ker, 2017), offers a possible solution - to invite every learner to bring their culture to their learning. This has potential to enable significant change, and the nature of such transformation will be further explored in the next section. 


\section{TRANSFORMATION FOR IMPACT}

In a pioneering work, Meadows (1999) argued that leverage points are the key to impactful change. This has relevance when designing fit-for-purpose learning for a disrupted future. Abson et al. (2017) suggest that there is an urgent need to focus on less obvious, but potentially far more powerful areas of intervention, with three leverage points having the potential to act as a boundary object for genuinely transformational sustainability:

I. Reconnecting people to nature

2. Restructuring institutions

3. Rethinking how knowledge is created and used in pursuit of sustainability.

Such leverage points do not happen for individuals in isolation from others, but rather with others. In learning contexts, a community of practice (CoP) functions as a space of situated learning characterised by three main features - mutual engagement, joint enterprise and a shared repertoire (Wenger, 1998). Members' senses of belonging and wanting to belong come from their abilities to engage in activities beneficial to the group, and also from the shared nature of their objectives and the discourse (repertoire) of the community. This means that everyone can make a contribution which might help others; at the same time, the shared experiences and wisdoms of group members can increase expertise across the group (Henry et al., 2020).

In successful CoPs, there is a balance of benefit for both the community and the individuals who make it up (Andrew, 2014), and a sense of the more novice members reaching learning goals through legitimate peripheral participation (Lave \& Wenger, 199I). Lave and Wenger envisage a CoP as a series of concentric circles, with the target knowledge and repertoire situated in an innermost circle - that of the experts. Participating peripherally are the learners, who learn by a process of observation that becomes increasingly participative with time and the building of trust. (Henry et al., 2020).

While designing learning CoPs for transformational impact has long been at the heart of activism, most activism fails to transform complex issues because it has a single-issue focus, rather than a 'root cause' approach which requires learning (Narberhaus \& Sheppard, 2015). Attempting to motivate people with messages of urgency and scenarios of threat doesn't work - the peril becomes normality and the effect vanishes (ibid). In organisations willing to learn, there is increased trust and ability to collaborate. Designing organisations where people can bring themselves more fully to work will result in more elegant solutions to complex challenges. This increasing trust in a time of disruption brings into question the place of people's wellbeing as a measure of response (Laloux, 20 I4).

By focusing on meeting human needs, we can navigate ambiguity through empathy, expansive thinking and experimentation. As Robinson (2006) stated in a landmark TED talk (view at TED2006, "Do schools kill creativity?," with 66 million views at 12 August 2020), education design should be based on the richness of human capacity. Self-determined learning is a way to customise learning for each individual, if capability development is used as the measure of success.

Capable people are more likely to deal effectively with the turbulent environment in which they live by possessing an all-round capacity centred on self-efficacy, knowing how to learn, creativity, the ability to use competencies in novel as well as familiar situations, and by working with others (Wade \& Kenyon, 20 I3). Educating for capability rather than knowledge can be the common language of success, as suggested by the twenty-first century skills summarised in Figure 6. 


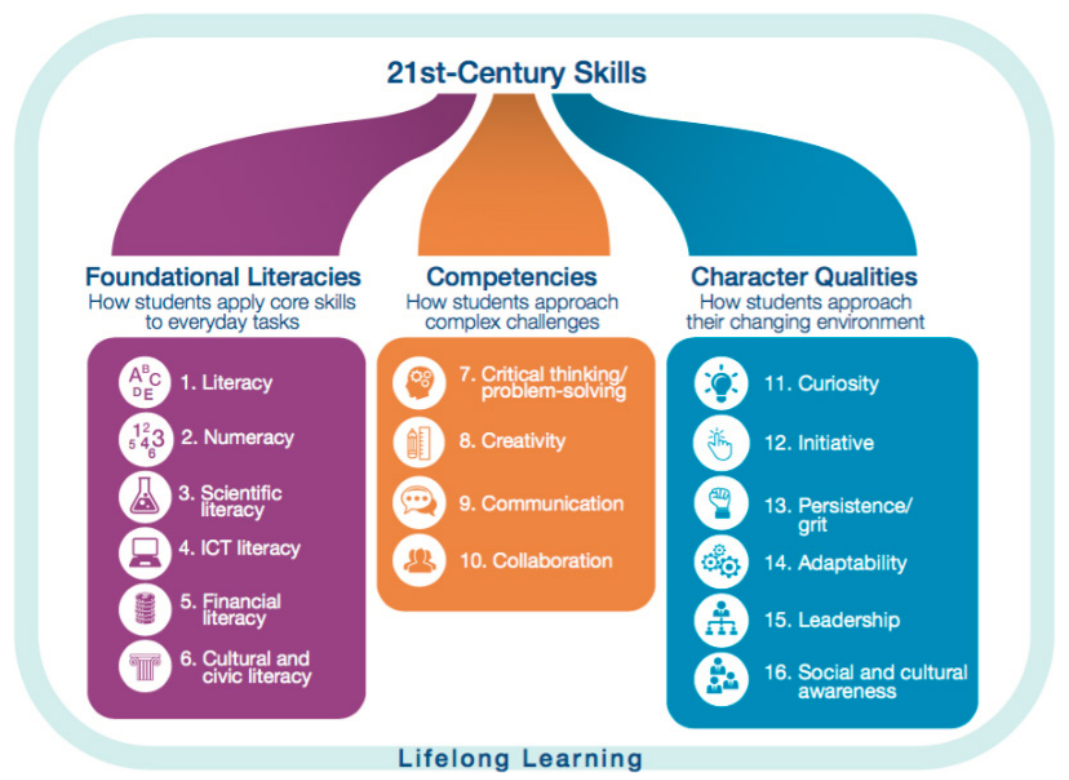

Figure 6. 2 Ist-Century Skills (World Economic Forum, 20I5).

The only capability-based, self-determined bachelor's degree in Aotearoa-New Zealand - the Bachelor of Leadership for Change at Capable NZ, Otago Polytechnic - has the following learning outcomes (Otago Polytechnic, 2018, p. 15):

I. Apply competencies and capabilities to enable transformational change in communities, enterprises and environments.

2. Integrate an appreciation of the bicultural context of Aotearoa New Zealand and the Treaty of Waitangi within an emergent professional framework.

3. Articulate ethical and sustainability frameworks such that they [learners] act as sustainable practitioners.

4. Recognise and incorporate one's own values, mindsets and biases within a grounded theoretical framework.

5. Create and maintain healthy relationships and collaborations in communities and organisations.

6. Synthesise experiences, capabilities and competencies to create an emergent professional framework of practice.

These learning outcomes invoke a sense of opportunity rather than prescriptive reductionism. Learners determine how they achieve them with the support of learning infrastructure and facilitators. During the coronavirus pandemic, this programme was not disrupted.

Changing one's mindset from what is wrong to what is possible is the essence of capability building and the role of learning programmes. The squeeze in a disrupted higher education future, as portrayed in Figure 3, focuses on the drivers of change that are problematic rather than what opportunities this invokes. Reed and Mang (20I2) have articulated what regenerative futures look like, compared to conventional futures. In their trajectory of ecological design (Figure 7), they introduced a language for articulating what is possible and a mindset of trajectory from a mechanistic to an ecological world view. 
The Regenesis Group (2020) began articulating theoretical and practical foundations for regenerative development in the mid-1990s, providing a useful lens for understanding how a practice can emerge from and be shaped by a world view that includes both theory and praxis, with its continuing development drawing explicitly on the scientific and philosophical bases of the ecological world view and a regenerative paradigm (Mang \& Reed, 20I2).

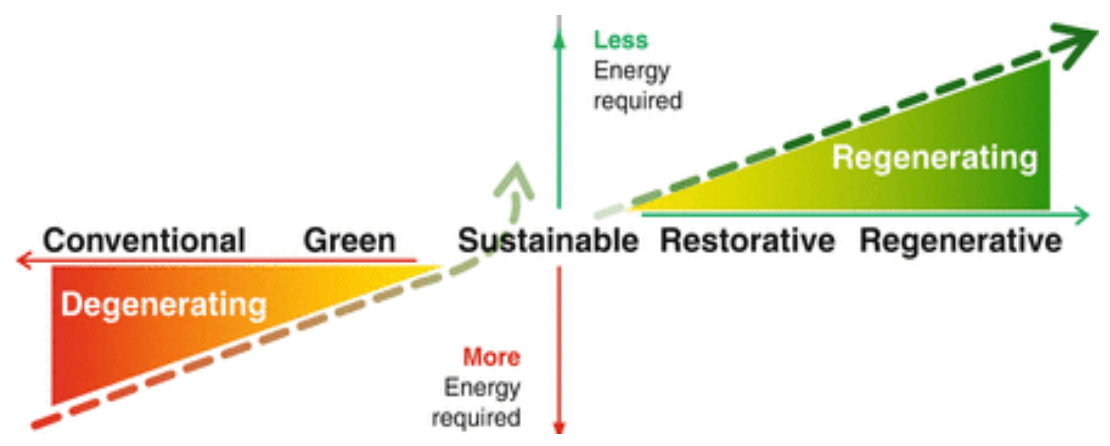

Figure 7.Trajectory of ecological design (Mang \& Reed, 20I2).

Robinson (2016) took these ideas and presented them visually in Figure 8, where conventions are seen as unsustainable and the way to enable regenerative practice is to pass through the squeeze of the constraints to enable flourishing in regenerative practice (Wahl, 2016). The linear conventional system of Education 1.0 evolves into the cyclic system of Education 3.0, where the success of one learner spirals outwardly, with no set limit of learning. Put another way, there are three lines of work to the development of regenerative practice (Mang \& Reed, 20|2):

I. The practice of development of the self

2. the practice of development of the community encountering the change; and

3. the practice of development of the wider system. Such simultaneous practice creates regenerative cultures (Wahl, 2016).

An education system can be regenerative by design if it designs for these practices. Self-determined learning is a design which is better suited to enable such practice, providing a language of what is possible in regenerative design. The conventional learning systems of Education 1.0 and 2.0 are mechanistic, with conventions that prescribe curricula in a setting determined by experts, requiring a lot of energy to operate. Self-determined education, anywhere, anytime - Education 3.0 - is regenerative. This is because it is customised for each individual and learners are enquiring of themselves, rather than attempting to fit into someone else's idea of success for them.

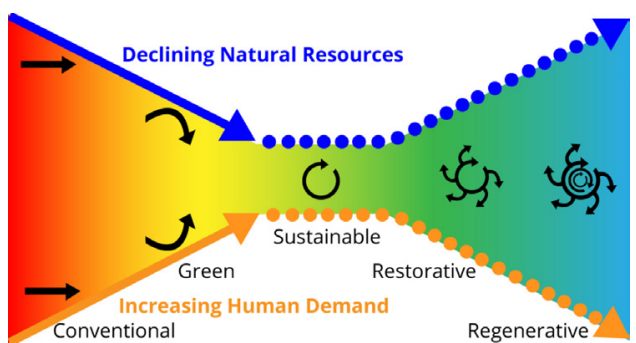

Figure 8. From conventional to regenerative design (after Robinson, 2016).

\section{LOOKING FORWARD}

The rate of change in higher education is accelerating. The perfect storm ${ }^{3}$ of a system under capacity pressure and economic stress (Oosterman et al., 2017) from a looming transformation (Filho et al., 2017) and a worldwide pandemic indicates that education is surely set to follow other industries which have faced disruption and experienced major change.

Self-determined Education 3.0 learning is a possible - perhaps inevitable - response to this disruption. 
Inclusive, accessible, affordable and based on the creative potential of human capacity, with a shared understanding of the object and nature of transformation, the education systems of the future will share little with traditional, campus-bound pedagogy.

Determining suitable responses from institutions, facilitators and their learners is emerging as a key component of the author's doctoral enquiry. It is becoming evident that the future of learning could be modelled around individual enquiry based in a community of practice such as a workplace, where each individual - initially a peripheral participant - with time and confidence will enhance and benefit from collective learning. We can have an education system drawing on all of the richness of human capacity.

\section{ACKNOWLEDGMENT}

Early versions of this paper benefitted from the contributions of Dr Malcolm Macpherson, a colleague at Capable NZ.

Contact details: steve.henry@op.ac.nz

Abson, D. J., Fischer, J., Leventon, J., Newig, J., Schomerus, T., Vilsmaier, U., ... Lang, D. J. (2017). Leverage points for sustainability transformation. Ambio, 46, 30-39. https://doi.org/ I 0.1007/s I 3280-016-0800-y

Anderson, N. (2020, July 7). A tuition break, half-empty campuses and home-testing kits: More top colleges announce fall plans. The Washington Post. Retrieved from https://www.washingtonpost.com/education/202\%7/06/harvard-reopen-with-fewer-thanhalf-undergrads-campus-because-coronavirus/

Andrew, M. (20I4). Community and individuality: Teaching and learning insights from a postgraduate online writing program. SAGE Open, 4(3), I-13. Retrieved from https://doi.org/10.1 I77/2158244014544292.

Anon. (2020, 22 February). Polytech merger offers 'no real surprises.' Otago Daily Times. Retrieved from https://www.odt.co.nz/ news/dunedin/campus/otago-polytechnic/polytech-merger-offers-\%E2\%80\%98no-real-surprises\%E2\%80\%99.

Atkins, L., \& Flint, K. J. (2015). Nothing changes: Perceptions of vocational education in England. International Journal of Training Research, 13(I), 35-48. https://doi.org/10.1080/14480220.2015.1051344.

Bhoyrub, J., Hurley, J., Neilson, G. R., Ramsay, M., \& Smith, M. (2010). Heutagogy: An alternative practice based learning approach. Nurse Education in Practice, 10(6), 322-326.

BoardShare (n.d.). 8 Ways Open Pedagogy Benefits Teachers and Learners [Blog post]. Retrieved from https://myboardshare.com/ blogs/8-ways-open-pedagogy-benefits-teachers-and-learners.

Buckminster Fuller, R. (1969). Operating manual for spaceship earth. Carbondale, IL: Southern Illinois University Press.

Bull, B. (20|4). Embracing opportunities for self-directed learning in formal learning environments. In L. Blaschke, C. Kenyon \& S. Hase (Eds.), Experiences in self-determined learning (pp. 33-48). Oldenburg, Germany: Centre for Open Education Research (COER), University of Oldenburg.

Christensen, C. M., Waldeck A., \& Fogg, R. (2017, October 30). The innovation health care really needs: Help people manage their own health. Harvard Business Review. Retrieved from https://hbr.org/2017//0/the-innovation-health-care-really-needs-helppeople-manage-their-own-health.

Durie, M. (2005). Indigenous higher education: Māori experience in New Zealand. An address to the Australian Indigenous Higher Education Advisory Council, Canberra, Australia. Retrieved from https://www.researchgate.net/profile/Mason_Durie/ 
publication/242744367_INDIGENOUS_HIGHER_EDUCATION_ADVISORY_COUNCIL/links/573d839008aea4 5ee842959e.pdf.

Education Central. (2019, February 14). Strong and mixed reactions to the proposed vocational education reforms. Retrieved from https://educationcentral.co.nz/strong-and-mixed-reactions-to-the-proposed-vocational-education-reforms/

Eisenstein, C. (2020, March). The coronation. Retrieved from https://charleseisenstein.org/essays/the-coronation.

Filho, W. L., Raath, S., Lazzarini, B., Vargas V. R., de Souza, L., Anholon, R., \& Orlovic, V. L. (2018). The role of transformation in learning and education for sustainability. Journal of Cleaner Production, 199, 286-295. Retrieved from https://www.sciencedirect.com/ science/article/pii/S095965261831984X.

Friday, C., \& Halloran, L. (2019). How the universities of today can lead learning for tomorrow. Retrieved from https://www.ey.com/ en_nz/government-public-sector/can-the-universities-of-today-lead-learning-for-tomorrow.

Hase, S., \& Kenyon, C. (2000). From andragogy to heutagogy. Ulti-BASE In-Site, December. Retrieved from https://epubs.scu.edu.au/ gcm_pubs/99/.

Hase, S., \& Kenyon, C. (2003, September 25-27). Heutagogy and developing capable people and capable workplaces: Strategies for dealing with complexity. Paper presented at the Changing Face of Work and Learning conference, University of Alberta, Alberta, Canada.

Hase, S., \& Kenyon, C. (2013). Self-determined Learning: Heutagogy in action. London \& Oxford, UK: Bloomsbury.

Henry, S., Te Maihāroa, K., Gaulter,..,Woodward, D., Hogan, R. \& Andrew, M. (2020, in press). Communities of practice for independent learning practitioners at Capable NZ, Otago Polytechnic. Scope (Learning and Teaching), 9.

Henry, S., Te Maihāroa, K., Gaulter, J., Woodward, D., Hogan, R. \& Andrew, M. (2020). Communities of practice for independent learning practitioners at Capable NZ, Otago Polytechnic. Scope Work-based learning 1.

Hess, A. (2020, June 19). 7 ways the coronavirus pandemic could change college this fall and forever [Blog post]. Retrieved from https://www.cnbc.com/202\%6/19/7-ways-coronavirus-pandemic-may-change-college-this-fall-and-forever.html.

Horn, M. (20I4, March 17). KAIST doesn't wait for change in Korea, pioneers 'Education 3.0' [Blog post]. Retrieved from https://www. forbes.com/sites/michaelhorn/20 /4/03/I7/kaist-doesnt-wait-for-change-in-korea-pioneers-education-3-0/\#3b2f4f5326ec.

Huitt,W. (200I). Humanism and open education. Retrieved from http://www.edpsycinteractive.org/topics/affect/humed.html.

Hunt, D. (2020,May 14). Hey white women:Māori culture is not your birthright [Blog post]. Retrieved from https://weakandstrongblog. wordpress.com/202\%5/I 4/hey-white-girls-maori-culture-is-not-your-birthright.

Kerr, C. (200I). The uses of the university. Cambridge, MA: Harvard University Press.

Ker, G. R. (2017). Degrees by independent learning: A case study of practice at Otago Polytechnic, Dunedin, New Zealand [Unpublished DProfStudies (Adult Learning) thesis]. Middlesex University, London, UK.

Laloux, F. (20|4). Reinventing organizations: A guide to creating organisations inspired by the next stage in human consciousness. Paris, France: Éditions Diateino.

Lave, J., \& Wenger, E. ( 199 I). Situated learning: Legitimate peripheral participation. Cambridge, UK: Cambridge University Press.

Lyngsø, L. (2017). The gamechangers. Retrieved from https://futurenavigator.com/the-gamechangers.

Mang, P., \& Reed, B. (20I2). Regenerative development and design. In R. A. Meyers (Ed.), Encyclopaedia of Sustainability Science and Technology (2nd ed., pp. I-36). Retrieved from https://www.researchgate.net/profile/Pamela_Mang/publication/32I I 56684_ Update_Regenerative_Development_and_Design_2nd_edition/links/5al la93 I 0f7e9bd l b2c0bc9c/Update-Regenerative-

Development-and-Design-2nd-edition.pdf.

Mann, S., Eden-Mann, P., Smith, L., Ker, G., Osborne, P., \& Alexander-Crawford, P. (2017). A transformation mindset as the basis for sustainable community development. Paper presented at the International Conference of the Association of Community Development, Auckland, New Zealand. Retrieved from http://www.unitec.ac.nz/epress/wp-content/uploads/20 I7/07/ACDAIACD-2017-proceedings.pdf.

Maslow, A. H. (1943). A theory of human motivation. Psychological Review, 50(4), 370-396.

Meadows, D. (1999). Leverage points: Places to intervene in a system. Retrieved from http://donellameadows.org/archives/leveragepoints-places-to-intervene-in-a-system.

Mezirow, J. (1997). Transformative learning: Theory to practice. In P. Cranton (Ed.), Transformative learning in action: Insights from practice (new directions for adult and continuing education) (pp. 5-1 I). San Francisco, CA: Jossey-Bass.

Ministry of Education. (2019). Summary of submissions for the reform of vocational education. Retrieved from https://conversation. education.govt.nz/assets/RoVE/AoC/Reform-of-Vocational-Education-Summary-of-Public-Consultation-and-Engagement.pdf.

Moravec, J. (2008). New paradigm model - Education 1.0-3.0 spectrum. Retrieved from https://usergeneratededucation.files. wordpress.com/2013/03/6419005939_1057dda70e_b.jpg. 
Narberhaus, M., \& Sheppard, A. (20/5). Reimagining activism: A practical guide for the great transition. Retrieved from http://www. smart-csos.org/images/Documents/reimagining_activism_guide.pdf.

New Zealand Productivity Commission. (2019). Training New Zealand's workforce:Technological change and the future of work (Draft report 3). Retrieved from https://www.productivity.govt.nz/assets/Documents/42852dd6a2/Draft-report-3_Training-NewZealands-workforce.pdf.

Olsson, P., Folke, C., \& Hahn, T. (2004). Social-ecological transformation for ecosystem management:The development of adaptive co-management of a wetland landscape in southern Sweden. Ecology and Society, 9(4), Art 2. Retrieved from https://www. ecologyandsociety.org/vol9/iss4/art2.

Oosterman, J., Sedgwick, C., \& Grey, S. (n.d.). Education under pressure. The 2016 New Zealand tertiary education state of the sector survey. Retrieved from http://media.nzherald.co.nz/webcontent/document/pdf/20 I 7/ 3/Education\%20Under\%20Pressure\%20 Reporl.pdf

Otago Polytechnic. (2018). Bachelor of Leadership for Change programme document [Unpublished document].

Pferdt, F. (2020). What design thinking can teach us about teamwork in a world on pause [Blog post]. Retrieved from https://www. thinkwithgoogle.com/marketing-resources/organizational-culture/human-centered-design-thinking/?fbclid=lwAROUh22vrtRb ljXQr_4zuelK49tY4KlyFho4nX-floab_DSKWNXzyOOt89E.

Regenesis Group. (2020). Regenesis [Home page]. Retrieved from www.regenesis.com.

Robinson, A. (2016). From conventional to regenerative design [Graphic]. Final report, Graduate Diploma in Sustainable Practice, Otago Polytechnic [Unpublished document].

Robinson, K. (2006). Do schools kill creativity? (TED2006) [Video file]. Retrieved from https://www.ted.com/talks/sir_ken_robinson_ do_schools_kill_creativity.

Smith, L.T. (2008). Decolonising methodologies. Dunedin, NZ: Zed Books and University of Otago Press.

Smith, M. D. (2020, June 22). Are universities going the way of CDs and CableTV? The Atlantic. Retrieved from https://www.ey.com/ en_nz/government-public-sector/can-the-universities-of-today-lead-learning-for-tomorrow.

Spiller, C., Barclay-Ker, H., \& Panoho, J. (2013). Wayfinding leadership; Groundbreaking wisdom for developing leaders. Auckland, NZ: Huia.

Tabarrok, A. (2020). Annual streaming price [Tweet]. Retrieved from https://twitter.com/ATabarrok/status/I 28 I 262303057448960.

Tertiary Education Commission. (2019, December). The tertiary education strategy. Retrieved from https://www.tec.govt.nz/focus/ our-focus/tes.

Wahl, C. (2016). Designing for regenerative cultures. Axminster, UK:Triarchy Press.

Wall Street Journal. (2020, April 7). A college refund for coronovirus? Wall Street Journal. Retrieved from https://www.wsj.com/ articles/a-college-refund-for-coronavirus- I 1586299536.

Walsh, J. D. (2020, May II). The coming disruption. New York Magazine: Intelligencer. Retrieved from https://nymag.com/ intelligencer/202\%5/scott-galloway-future-of-college.html.

Wenger, E. (1998). Communities of practice. Cambridge, UK: Cambridge University Press.

World Economic Forum. (2015). New vision for education: Unlocking the potential of technology. Retrieved from http://www3. weforum.org/docs/WEFUSA_NewVisionforEducation_Report20 I5.pdf.

I For a contemporary introduction to the transformation/disruption literature, especially the landmark articles and books by Christensen, go to https://hbr.org/20 I 2//2/surviving-disruption; https://hbr.org/2020/0 //the-essential-clayton-christensenarticles; and especially, https://sloanreview.mit.edu/article/an-interview-with-clayton-m-christensen/?gclid=EAlalQobChMI7ta oqu6P6wIVJ9WWCh2VuAcGEAMYAiAAEgJIF_D_BwE.

2 For a contemporary definition, see https://www.ncbi.nlm.nih.gov/pmc/articles/PMC7268589.

3 https://www.collinsdictionary.com/dictionary/english/perfect-storm. 